\title{
Hindistan Babürlü Devletinde Yazılan Çağatayca Sözlüklerde Devlet Yönetimi ve Askeri Teșkilatla İlgili Kelimelere Dair
}

\section{On the Lexical Materials Concerning the State Administration and Military Organisation Included in the Chagatay Dictionaries Written in Mughal India}

\author{
Fikret Turan ${ }^{1}$
}

${ }^{1}$ Prof. Dr., İstanbul Üniversitesi, Edebiyat Fakültesi, Türk Dili ve Edebiyatı Bölümü, İstanbul, Türkiye

ORCID: F.T. 0000-0003-3532-3910

Sorumlu yazar/Corresponding author: Fikret Turan,

İstanbul Üniversitesi, Edebiyat Fakültesi, Türk Dili ve Edebiyatı Bölümü, B Blok, Kat:3, No: 14, Fatih, İstanbul, Türkiye

E-mail: fikretturan@hotmail.com

Başvuru/Submitted: 12.02.2019

Revizyon Talebi/Revision Requested: 20.05.2019 Son Revizyon/Last Revision Received: 28.05.2019 Kabul/Accepted: 29.05.2019

Online Yayın/Published Online: 28.06.2019

\section{Atrf/Citation:}

Turan, F. (2019). Hindistan Babürlü Devletinde yazılan Çağatayca sözlüklerde devlet yönetimi ve askeri teșkilatla ilgili kelimelere dair. TUDED 59(1), 203-220

https://doi.org/10.26650/TUDED2019-0002
ÖZET

Hindistan'da kurulan Babürlü Devletinin resmi dili Farsça olmasına rağmen devlet yöneticileri ile askerî görevliler kendi aralarında Çağatay Türkçesini bir kimlik unsuru olarak kullanmaya devam etmișlerdir. Yönetici kesim, çocuklarının ve aile mensuplarının Türkçeyi öğrenmeleri için çok sayıda Farsça açıklamalı Çağatay Türkçesi sözlük, gramer ve okuma kitapları yazdırmışlardır. Bu eserlerin en önemli özelliklerinden birisi Türkçe ve Türkçeleşmiş birçok kelime ve tamlamanın Babürlü Devletinde kazandığı kendine özgü yeni anlamları açıklaması ve bu devlette kullanılmaya başlayan yeni kelime, terim ve ifadeleri göstermesidir. Bu çalıșmada Hindistan'da yazılmıș Nișāb-ı Kutbiyye, Nișāb-l Türk̄̄ der Lugiat, Nișāb-ı Türkī ve Zübdetü'l-Esmā'i 't-Türkiyye isimli dört sözlükte devlet yönetimi ile ordu teşkilatına dair bir semantik alt katman olarak ortaya konan leksik veriler incelenerek bu alandaki özgün kelimeler ile semantik oluşumlar açıklanmıştır. İncelediğimiz sözlüklerde daha önceki Türk veya İslam devletlerinde idari ve askerî sistem içinde kullanılmayan veya çok sınırlı kullanımı olan kelimeler ile daha önceki dönemlerde kullanılan, ancak Babürlü Devletinde anlam değișimine uğrayan önemli sayıda kelime ve tamlamalar tespit edilmiştir. Bu sözlüklerde görülen idari ve askerî kelimelerin önemli bir kısmı da daha önce Timurlular döneminde de kullanılan ve Türkçeleşmiş Moğolca kökenli dil unsurlarıdırlar.

Anahtar Kelimeler: Çağatay Türkçesi, Çağatay sözlükleri, Farsça-Çağatayca sözlükler, Hindistan Babürlü Devletinde Türkçe, Türkçe askerî ve idari terimler

\section{ABSTRACT}

Although Persian was the official language of the Mughal Empire, members of the administrative and military classes continued speaking Chagatay Turkic among themselves as a sign of identity. In order to have their children learn Chagatay Turkic as well, they had many Chagatay dictionaries, grammars and language learning books with Persian instructions written. One of the most prominent characteristics of these works is that they demonstrate newly emerging lexical items and explain a number of Turkic and Turkicised lexical elements with new meanings. In this article, by analysing four Chagatay dictionaries including Nișāb-ı Kutbiyye, Nișāb-ı Türkī der Luġat, Niṣāb-ı Türkī and Zübdetü'l-Esmä'it-Türkiyye, written in Mughal India, I explore the lexical items concerning the state administration and military organisation as a semantic substratum and explain the unfamiliar and original lexical units and semantic formations in them. Some of the lexicon that appears in these dictionaries were either not used or had a very limited use in the administrative or military systems of previous Turkic or Islamic states. They also provide certain old lexical items that gained new meanings during the period of the Mughals. An important part of the administrative and military lexis used in the Moghul State, as well as those used in the Timurid period, are of Mongolian origin.

Keywords: Chagatay Turkic, Chagatay Dictionaries, Persian-Chagatay Dictionaries, Turkic in Mughal India, Turkish/Turkic Terminology of State Administration and Military 


\section{EXTENDED ABSTRACT}

In this article, by analysing four Persian-Chagatay Turkic dictionaries entitled Niṣāb- $\iota$ Kutbiyye, Niṣāb-ı Türkī der Luğat, Niṣāb-ı Türkī and Zübdetü'l-Esmā 'i 't-Türkiyye written in Mughal India, I explore the lexical materials on state administration and military organisation as a semantic substratum and explain unique and original lexical units and semantic formations in them.

These dictionaries explain many words and phrases used as administrative and military terms in the Mughal State. The linguistic features of these words and phrases are as follows:

a. Some of the vocabularies that appear in these dictionaries were either not used or had a very limited use in the administrative or military systems of previous Turkic or Islamic states. The words that became administrative and military terms in the Mughal India are: alug̣çı (tax collector), basalġa (raid troops), berikī (treasurer, high state official), boynag்u (rebel, mutineer), böyrekçi (troops at the flanks, trapper troops) èletmiş (vanguard), esre (watchman), kapuçı (troops at the flanks, trapper troops), küçüm (timariot), öçek (throne), öründük (throne), tabçı (strongman, sultan, chief), tuḳbay (chief chamberlain, commander), yapçı (messenger, go-between).

b. These dictionaries provide certain old vocabulary items that gained new meanings during the period of the Mughals. These are: ahtaça (head groom), ak (sultan's arbour), aḳça (rupi, coin), bahşi (general, chief commander, high state official), basturma (raid troops), başlıḳ (commander), bèy (sultan, chief commander), çalış (overseer, guard, chief), çavuş (vanguard), çėrikçi (timariot), èrçi (messenger, go-between), èşik ag̉ası (treasurer, high judge, high state official), ḳalmaḳ (sultan), ḳara (a small coin, penny), kèleçi (courier, dispach), ḳızıl (gold coin), ḳoruḳmal (guard, village guard), ḳoşun bègi (commander of ten thousand troops), ḳurgaançı (guard, village guard), müşrīf (high bureaucrat, high official), saḳlaçı (watchman, guard), tilçi (spy), töreçi (prosecutor, lawyer), tura (sultan), tutḳavul (advance guard, raider), yasa $\sim$ yasal (patrol squad, police squad), yol urġuçı (bandit, brigand).

c. An important part of the administrative and military vocabularies used in the Moghul State are of Mongolian origin and some of these were previously used in the Timurid period as well. Babur Shah, the founder of the Mughal dynasty, was a descendant of Genghis Khan by the lineage of his mother, which explains the place and significance of the Mongolians and the Mongolian language in the Mughal State. The words of the Mongolian origin observed in these dictionaries are: ahta (gelding), barangar burangar (army troops at the right flank), batur (warrior, war hero), çarangar $\sim$ çurangar (army troops at the left flank), çındavul (army troops at the back ranks), daruga (governor, chief bureaucrat and commander), gol (army troops at the center), rravul hiravul (army troops at the front lines), yasa $\sim$ yasal $\sim$ yasavul (patrol squad, police squad).

d. Some of the Turkic lexic in this semantic area had undergone certain phonological and morphological changes and took new forms: èrçi (messenger < èlçi), èşik ag̉a (treasurer 
< ėşik ag̉ası), küşlük (village chief < küçlük), yapçı (messenger <yapġuç1), saklaçı (guard $<$ saklag̉uçı), yav yavġ̀ (enemy <yag்1).

e. Most of the lexical units are derived forms from certain roots. Structures of the derived words are as follows:

i. The majority of the derived words are constructed by the suffix of the profession and habit +çI: aluġçı (tax collector), bitikçi (scribe), böyrekçi (troops at the side flanks), çėrikçi (timariot, landed commander), èrçi (messenger), ėşikçi (door guard), ḳarakçı (bandit), ḳorukç̧ı, ḳurg̉ançı (guard, village guard), tabçı (sultan), tilçi (spy), topçı (cannoneer), töreçi (prosecutor), tug̣çı (royal sealer), uruşçı (warrior), yayçı (bowyer).

ii. The denominal noun and adjective suffix + lIk has a common usage in the derivation: başlık (commander), bėklik (rank of high commander, state), èrklik (sultan), èrtelik (sultan), könüllük (bouncer, volunteering warrior), küçlük küşlük (village head).

iii. Participial suffixes have also a wide use: èletmiş (advance guard, raider), kèleçi (courier, <kelgüçi), ḳurġan (major fortress < ḳoruġan), öründük (throne), saḳlaç1 (watchman <saḳlag̉uçı), tutg̉un (prisoner of war), yol urg̉uçı (bandit), yol tutḳuçı (bandit).

iv. The equative +çA has a rather limited use: aķça (coin, rupi), ahtaça (head groom).

v. The denominal noun suffies +aġu (boynagiu 'rebel'), +ma (basturma 'raid troops'), +mal (koruḳmal 'guard, village guard'), the Arabic suffix of nisba +ī (bègī 'nobleman', berikī 'treasurer'), and the deverbal -Alg̀A (basalga 'raid troops at the back rank') are rarely used suffixes.

f. Some of the terms in question consist of two words. Most of these structures are in the form of the indefinite noun phrase having the following features:

i. Most of the phrases of this type include the words "agia," (leader) "baş" (head) and "bèg" (chief, commander) indicating leadership, being the modified element within the modifier-modified construction: bẻkler bėgi (chief commander), èşik ag̉ası (treasurer, chief judge), ḳoşun bègi (colonel, commander of ten thousand men), miñ başı and miñ bėgi (major, commander of one thousand men), on başı and on bègi (corporal, commander of ten men), topçı başı (artillary officer), tümen başı and tümen bègi (major, commander of one thousand men), yüz başı (captain, commander of one hundred men)

ii. A small number of the terms are constructed within the suffixless noun phrase: çerik başlık (general), èşik ag̉a (treasurer, chief judge), tuḳbay (head chamberlain).

iii. One item is in the adjectival phrase: iki kara (a small coin).

iv. Two synonymous items are constructed within the participial construction: yol urġuçı $\sim$ yol tutḳuçı (bandit). 


\section{GİRIŞ}

16. yüzyılın başlarında Babür Şah tarafından bugünkü Afganistan, Pakistan ve Kuzey Hindistan bölgelerini kapsayan coğrafyada kurulan Babürlü Devletinin kısa süre içinde bir imparatorluk haline geldiği bilinen bir gerçektir. Babür Şah döneminde devletin dili Çağatay Türkçesi olsa da onun oğlu Hümayun Şah döneminden itibaren devletin resmi yazışma ve edebî dili Farsça olmuş, bu durum son Babürlü padişahı İkinci Bahadır Şah’ın İngilizler tarafından sürgüne gönderildiği 1858 yılına kadar devam etmiştir. Bununla birlikte, Çağatay Türkçesi, başta padişahların çocukları ve akrabaları olmak üzere devletin üst düzey memurları ile ordu teşkilatının bildiği ve kullandığı dil olmuştur. Bu yönetici sınıf Türkçe bilmeyi ve konuşmayı kendilerini diğerlerinden ayıran bir kimlik unsuru olarak değerlendirmiştir. Bundan dolayı, başta padişahlar ve devletin ileri gelenleri Türkçeyi unutmaya başlayan çocuklarının Türkçe öğrenmeleri için Farsça açıklamalı Türkçe gramerler, sözlükler, atasözleri derlemeleri ve konuşma kılavuzları yazdırmışlardır. Bu türden eserlerin bir kısmı bugün Hindistan, Pakistan ve İran'daki kütüphanelerde bulunsa da önemli bir kısmı İngiltere'deki farklı kütüphanelerde saklanmaktadır. Bu eserler esas olarak Çağatay Türkçesinin dil özelliklerini yansıtır, ancak sık sık diğer Türk lehçelerindeki kelimelere ve gramer kurallarına dair bilgiler de sunarlar. Bu eserlerin en önemli özelliklerinden bir diğeri de Hindistan'da kurulan bu devlette Türkçe ve Türkçeleşmiş birçok kelimenin kazandığı kendine özgü yeni anlamları açıklaması ve burada kullanılmaya başlayan yeni kelimeleri göstermesidir ${ }^{1}$. Bu bağlamda, biz bu çalışmada Babürlü Devletinde devlet yönetimine ve ordu teşkilatına dair çok sayıda Türkçe kelimeyi açıklayan Hindistan kaynaklı dört adet Farsça-Çağatay Türkçesi sözlükte bulunan söz malzemesini inceleyeceğiz. Bu incelemeyi yaparken esas amacımız bu devlet yönetimi ve askerî alanlardaki kelime hazinesinin özellikle Babürlü Devletinde kazandığı anlam inceliklerini ortaya koymak olacaktır.

Bu çalışma için inceleyeceğimiz eserlerden üç adedi manzum, bir adedi tematik mensur sözlüktür:

1. Nișāb-1 Kutbiyye (NK): 1837 yılında (H. 1252) yazılmış 274 beyitlik Farsça açıklamalı Çağatayca manzum sözlüktür. Yazarı Kelimetullāh Hुwāce Pādişāh’tır. British Library'de Or. 404 numaralı mecmuanın 93a ile110a sayfaları arasında bulunmaktadır. 9 bölüm (bāb) içinde sunulan 274 beyitten oluşmuştur. Yaklaşık 1.100 kelimelik bir sözlüktür. Eseri halihazırda bir monograf olarak yayına hazırlamaktayı.

2. Nișāb-1 Türk̄̄ der Lug̉at (NTDL): Hicri 1023 (Miladi 1614) yılında telif edilmiş eserde 22 bölüm (kıt'a) içinde 710 madde başı bulunmaktadır². Yazarı Muhammed Ya kūb Belhī’dir. Eserin iki nüshası vardır ve her iki nüshası da Manchester Üniversitesinin John Rylands Kütüphanesinde MS 63 ve MS 64 numaralarıyla saklanmaktadır. MS 63 numaralı

1 Hindistan Babürlü İmparatorluğu topraklarında yazılan Türkçe eserler ile Türkçe üzerine yapıllmış çalışmalar hakkında bkz. Schimmel 1981, Türkmen 1985, Turan 2009.

2 Her iki nüsha hakkında ayrıntılı katalog bilgisi için bkz. Schmidt 2011: 127-130. 
yazma 17 varaktan, MS 64 numaralı yazma ise 32 varaktan meydana gelmiştir. Birincide her sayfada 11, ikincide ise 7 satır bulunmaktadır. MS 63 Bodrogligeti tarafindan incelenerek yayımlanmıştır³.

3. Nișāb-1 Türkī (NT): 25 varaklık bu manzum sözlük Paris’te Bibliothèque Nationale'de Blochet Supplement Turc 1015 (Cilt II, sayfa 131) numarasıyla saklanmaktadır. Eserin telif ve istinsah tarihi gösterilmediği gibi yazarının ismi de yazılmamıştır. İçerdiği kelime hazinesi bakımından yukarıda ayrıntıları verilen John Rylands Kütüphanesinde iki nüshası bulunan NTDL ile bazı benzerlikler gösterir. 216 beyitten oluşan eserde 614 madde başı kelime vardır. Blochet, eserin yazarının Molla İla Yar Kıpçak Özbek Atacı olduğunu ve mevcut nüshanın Hicri 1265 (Miladi 1849) yılında yapılmış olduğunu bildirir. Eser, Sarıca tarafından yayımlanmıştır ${ }^{4}$.

4. Zübdetü'l-Esmā'i’t-Türkiyye (ZET): Telif ve istinsah tarihi gösterilmeyen, ancak 19. asırda kaleme alındığını düşündüğümüz tematik bir sözlüktür. Yazarı Seyyid Habbeddīn'dir. Eser, temalarına göre 9 bölümden oluşmuştur ve yukarıda açıklanan NḲ’nın da bulunduğu British Library'deki Or. 404 numaralı mecmuanın 79b ile 92 b sayfaları arasında bulunmaktadır. Henüz yayımlanmamıştır.

\section{Padișah ve Üst Düzey Yöneticilere Dair Kelimeler}

İncelediğimiz Çağatayca sözlükler o dönemde devlet yönetiminin başı olan hükümdarlık kavramı için Farsçadan alınan şāh, pādişāh / bādişāh kelimeleri ile Arapçadan alınan sultān kelimesini kullanırken aynı anlama gelen Türkçe kökenli önemli sayıda kelimeyi de ortaya koymaktadır. Padişah, yüksek devlet yöneticisi ve onlar adına hareket eden ordu komutanı anlamına gelen Türkçe kökenli veya erken dönemlerde Türkçeye girerek Türkçeleşmiş kelimeler şunlardır:

bahş̧i: 1. Yüksek rütbeli ordu komutanı, 2. Padişah olmadığı zaman padişah adına hareket eden en yüksek ordu komutanı, 3. Üst düzey bürokrat, (bẻkler bèki, emīrü'l- ‘ümerā ve hān-1 hānān, ZET 84b-13).

"Bahşi”" kelimesi köken olarak Sanskritçe bhikşi kelimesine dayansa da Çince üzerinden Eski Uygurcaya geçmiştir ve Eski Uygurca Budist metinlerde "Budist rahip, derviş veya din âlimi, şaman ve tabip" anlamlarında görülür (Clauson, 1972, 321). Bununla birlikte İslami dönemde, özellikle Babürlülerde, bu kelime "en üst düzey komutan, kâtip, tabip, haznedar, üst düzey devlet yöneticisi” anlamlarında kullanılmıştır. Babürlülerde devlet yönetiminde en üst düzey 4 ordu komutanı için çeşitli tamlamalar içinde bahş̧i kelimesi kullanılmış ve bu bağlamda en yüksek ordu komutanına "bahşiyü'l-memālik" veya "mīr bahşi”" denmiştir. Daha

3 Schmidt ve Bodrogligeti eserin telif ve istinsah tarihlerini birbirlerinden farklı yorumlamışlardır. Bkz. Bodrogligeti 1981 ve Schmidt 2011: 127.

4 Sarıca 2014. Bu eserin katalog ve içerik bilgileri kısmen bu çalışmadan naklen, kısmen de eserler arasında yaptığımız karşılaştırmaya istinaden oluşturulmuştur. 
aşağı rütbedeki bahşiler çeşitli ordu komutanlıklarını yürütmüşlerdir. Kelime her halükârda askerî teşkilat içinde çeşitli kademelerdeki general anlamında kullanılmıştır. Buna ek olarak vilayetlerde valilere bağlı yüksek düzeyli sivil bürokratlara da bahş̧i denmiştir (Irvine 1903, s. 39-40).

bėgī: Bey, komutan veya üst düzey yönetici çocuğu, asilzâde, (emīr-zāde, ZET 84b-15).

Kelimenin sonundaki uzun ünlünün Arapça nispet î’si olduğu açıktır.

bèk: 1. Ordu komutanı, 2. Vali, 3. Kabile reisi, 4. Asilzâde, (mīr ve ḥākim, emīr, NTDL 7a-5, ZE 84b-15).

Kelimenin anlamı sözlüklerde daha çok "emīr" olarak gösterilmiştir ve esas olarak büyük hakana veya padişaha bağlı küçük ve bölgesel yönetimlerin başı anlamına gelmektedir. Oğuzcada da Selçuklu sultanına bağlı yöresel yönetimlerin ve kabile birliklerinin başı anlamına gelir. Bu bağlamda Anadolu Beylikleri kavramı da bir tarihi terim olarak yaygındır. Timurlular döneminde ve Babürlü Devletinde büyük sultana bağlı yöresel liderler ile hanedana bağlı erkek üyeler için kullanılan emīr ve mīrzā kelimeleriyle eşanlamlı olarak görülür.

Orhun Yazıtlarında "Toḳuz Og̉uz begleri” yapısı içinde de görülen kelime sonraki dönemlerde Eski Uygur metinlerinde de yaygındır ve hemen bütün kullanımlarında "büyük hakana bağlı kabile reisi, yüksek rütbeli subay, şehzâde, asilzâde ve bunlar gibi seçkin devlet görevlisi veya lider" anlamlarına gelir. Metinlerde bėg/bėk veya beg/bek/bey şekillerinde görülen kelime ayrıca "efendi, haşmetmeab, hazret" gibi saygılı seslenme hitabı olarak da Türk dili ve lehçelerinde kullanılmıştır (Clauson 1972, s. 322-323).

Clauson, kelimenin kökeninin Çincede yüzbaşı anlamına gelen "po" kelimesine dayandırılabileceğini ileri sürer. Ancak bu etimolojik açıklama, "beg” kelimesinin tek heceli yapıda Türkçenin tarihi fonotaktiğine uygun olurken anlam yönünden "po" ile arasında uygunluk olmamasından dolayı zayıf bir görüş olarak durmaktadır. Zaten kendisinin bu dönüşümün hangi fonolojik esaslar dâhilinde oluştuğunu göstermemesi konuya dair ciddi bilimsel delillerinin olmadığı anlamına gelir. Ancak fonolojik ilkeler dikkate alındığında aksi bir görüş daha tutarlı olabilir. Yani kelimenin Türkçeden Çinceye geçmiş olabileceği düşünülebilir. Bu bakımdan Türkçe "beg” kelimesi Çinceye geçtikten sonra sondaki /g/ ünsüzünün sızıcılaşarak kaybolması ve /b/ dudak ünsüzünün etkisiyle /e/ ünlüsünün /o/ ünlüsüne dönüşümü $(\mathrm{e}>0)$ daha olası gözükmektedir: bėg $>$ bėy $>$ bei $>$ boi $>$ po.

bèkler bėgi: 1. En yüksek rütbeli komutan, 2. En büyük han, sultan, (emīrü'l-'ümerā, hān-1 hāāān, ZET 84b-13).

Sözlüklerde "ordu komutanı, en büyük emir veya hanlar hanı, en büyük sultan” olarak anlamlandırılan bu tamlama Osmanlı Devletinde "beylerbeyi" şeklinde daha çok "bölge valisi ve ordu komutanı” anlamında kullanılmıştır. Bununla birlikte sözlükler bu tamlamanın 
Babürlülerde bir idari terim olarak "baş komutan ve sultan” anlamına geldiğini belirtmiştir.

bėklik: 1. Ordu komutanlığı, beylik, büyük hana bağlı kabile ve vilayet reisliği, 2 . Devlet tarafından verilen arazi ve gelirler, (emīrī ve ḩāliṣe, ZET 84b-15).

bėy: Büyük emir, sultan, (emīr-kelān, ZET 84b-16).

"Bèk/beg" kelimesinin bir varyantı olan "bey" burada "hükümdar" anlamında gösterilmiştir.

èrklik: Padişah, (şāh, sāhib-i iḩtiyār, pādişāh, NḲ 101a-14, ZET 84b-6).

Güç, kudret ve ihtiyar anlamındaki "ėrk" kelimesiyle "+lık/+lik" sıfat ekinden oluşmuş bu kelime "güç sahibi” anlamından hareketle mecazen padişah için kullanılmıştır.

èrtelik: Padişah, (pādişāh, ZET 84b-6).

Kelimenin Farsçanın Zend ve Pazend lehçelerinde "memleket, yurt" anlamına gelen “ertā” kelimesiyle Çağataycada sıfat yapım eki olarak da kullanılan +lIk ekinden türemiş olması muhtemeldir: ertālik > ertelik > èrtelik (memleket sahibi) (Steingass, 1892, 33). Kelime bu bakımdan yapı yönüyle Eski Uygurca metinlerde görülen èlig / ilig < èllig / illig (halk ve ülke sahibi, hükümdar) kelimesiyle yapı ve anlam yönünden paralellik gösterir.

hāān: Padişah, (pādişāh, ZET 84b-6).

Kelime Göktürkçe "ḳaġan / hag̉an” kelimesinden dönüşen ve nadiren Tonyukuk Yazıtlarında, ancak çoğunlukla Eski Uygurca metinlerde "ḳan/ḳān” şeklinde görülen kelimenin sonradan Arapça, Farsça ve İslami dönem Türk lehçelerinde aldığı şekildir. Clauson, Köktürk ve Uygur yazısında / ḳ/ ve /h/ ünsüzlerinin aynı harflerle yazılmış olabileceğini bildirdikten sonra kelimenin "ḳag̉an” şekli yerine "ḩag̉an” şeklini sözlüğüne madde baş1 olarak almayı tercih eder. Bununla birlikte "haggan" kelimesinin Arapçaya ünlüleri uzayarak "hhāgāan" şeklinde girdiğini ve "ḩān" ve "ḩāgāan” şekillerinin morfolojik olarak birbirleriyle ilgilendirilemeyeceğini sebep belirtmeksizin ileri sürer (Clauson, 1972, 611). Kelime Moğolcaya da erken dönemlerde, büyük ihtimalle 13. yüzyılda geçen alıntı kelimelerden olmuştur. Biz, fonolojik olarak kelimenin ḳag̉an kelimesinden geldiğini düşünüyoruz. Buna göre iki ünlü arasındaki /g/günsüzünün süreklileşmesi ve sonra düşmesiyle iki ünlünün uzun ünlüye dönüşmesi Türk lehçelerinde görülen bir durumdur ve benzer gelişme "ḩān" kelimesinin oluşumunda da meydana gelmiştir: ḳag̉an > ḳān > ḩān.

ḳalmaḳ: Padişah, (bādişāh, ZET 85b-1).

Kelimenin anlamı "tabçı” (padişah, güçlü, büyük) anlamıyla aynı olarak gösterilmiştir (ḳalmaḳ rā nīz tabçı gūyend, ZE 85b-1). Kalmak, önceleri esasen Müslüman olmamış Moğol boylarından Kalmuklar ve Oyratlar için kullanılan bir boy ismi olsa da sonraları Türkleşmiş ve Müslümanlaşmış bir Özbek boyu için kullanılmıştır (Khalid, 1991). Kaynaklar Hindistan 
Babürlü Devleti içinde çeşitli ordu ve devlet memuriyeti görevinde önemli sayıda yerleşik Kalmak olduğunu ve bunların üst düzey komutan ve idarecilerin saflarında mücadele ettiğini belirtir (Faruqui, 2009). Kelimenin padişah anlamını destekleyen başka kaynağa rastlanamamıştır.

tabçı: Padişah, büyük ve güçlü, (merdī ki yāl ve bādişāh, ZET 85b-12).

Kelime, Eski Uygurcada "istek ve arzu" anlamındaki "tap" kelimesiyle + çI meslek ekinden "arzu ve istek sahibi" anlamıyla türemiş olmalıdır.

tura: Padişah, (hān, pādişāh, ZET 84b-6/7).

Kelime, Eski Uygurca Maniheyist metinlerde ilah Hurmuzda'nın beş oğlunun birincisi olan "nefes tanrısı" için kullanılan "tın tura" ikilemesi içinde ve "şehzâde" anlamında görülür. Bu kelime ilk dönem metinlerinde padişah tarafından belirlenmiş kanun, örf ve yasa için kullanılan "törü töre/türe" kelimesiyle aynı olmalıdır. Kelime sonradan Çağataycada padişahın, dinî kanunların (şeriatın) dışında belirlediği yasa ve örf anlamında kullanılmıştır. $\mathrm{Bu}$ duruma dayalı olarak kelime "tura" şekliyle sonradan yasayı koyan padişahla aynı anlamda, töre sahibi padişah anlamında kullanılır hale gelmiş olmalıdır (Clauson, 1972, 531). Kelimenin Osmanlılarda padişahın imzası işlevinde kullanılan tuğradan dönüştüğü bazı kaynaklarda ileri sürülse de kelimenin Timurlularda ve Babürlülerde bu anlamı yoktur. Çağatay Türkçesinde "tura" kelimesi, ayrıca asilzâdeler için kullanılan bir unvandır. Bu bağlamda unvan olarak kullanılan "turalik" kelimesi "efendilik ve şehzâdelik" anlamında kullanılır ki bunun Eski Uygurca Maniheyist metinlerde görülen kullanımına yakın olduğu açıktır (Ünlü, 2013, 1161).

\section{Hükümdara Ait Makam, Mekân ve Nişanlar}

aḳ: Padişaha ait süslü ve tezyinatlı teras veya kameriye (eyvān-1 şāh, ZET 84b-7).

Kelime büyük ihtimalle göçebe Türklere ait çadır veya yurt için kullanılan ve Nevâŷ̂ tarafından da tespit edilen "ak öy” sıfat grubuna dayanmaktadır (Barutçu-Özönder, 1996, 57). Babürlü padişah ve yöneticileri, yaptırdıkları süslü ve görkemli göçebe çadırına benzeyen teras ve kameriyeler için Orta Asya'daki geçmişlerinin bir unsurunu yaşatmak amaciyla olsa gerek “ak öy” kelime grubunun ilk kelimesini kullanmışlardır.

aḳça: Hindistan parası rupi, (rupi, NḲ 97a-10).

erk: Surlarla çevrili şehir içinde padişah ve ailesine ait müstahkem saray, (ḳalca būden-i şāh, ZET 84b-7).

iki ḳara: Az değerli bir sikke, (tenge, NḲ 109a-10).

ḳara: Az değerli bir sikke, kuruş, (fals, filūs, NḲ 109a-9). 
ḳızıl: 16 rupi değerinde altın sikke, (NK 109a-7).

Kelimenin çeşitli Türk lehçelerinde renginden dolayı önce mecazen altın için kullanıldığı, sonradan da bu mecazi anlamının yaygınlaşarak bazı lehçelerde daha yaygın ve hâkim hale geldiği görülür (Musayev, 1998, 371). Benzer durum altın sikke için de söz konusu olmuştur. Bu bağlamda altın sikkenin yapıldığı altın/ḳızıl, önce mecazen altın sikkeyi karşılamış, sonra bu mecazi anlam, altın sikke için kullanılan genel kelime olmuştur.

ḳurg̉an: Müstahkem büyük kale, (ḳalca-yi muḥkem, NT 17b-1).

öçek: Taht, (taht, ZET 84b-7).

Modern Urducadaki "uçek" (yüksek yer, yükselti) kelimesiyle de ilgili olan kelimenin “kubbe” anlamı Sekkāki Dīvānında geçer (Eşref \& Soydan, 2012, 27; Ünlü, 2013, 871).

öründük: Taht, padişahın oturduğu yüksek ve süslü koltuk, (mesned, ZET 84b-11).

Kelime Eski Uygurcada “yükselmek” anlamına gelen ör- fiilinden dönüşlülük -n ile sıfatfiil -dIk eklerinden oluşmuş olmalıdır.

tuġ: 1. Padişahlık tuğu, 2. Padişah tuğrası, (nişān, NḲ 97b-13).

yarlıg yarlık: Ferman, yarlık, menşur (fermān, NḲ 105b-12).

Kelime, Eski Uygurca döneminden beri yüksek makamda bulunun bir kişinin daha aşağı makamlarda bulunan kişilere yapılmasını buyurduğu yazılı emir, emirnâme anlamında kullanılmıştır. İslami dönemde padişahların emirlerini ve kararlarını bildiren ferman, berat ve menşur gibi kelimelerle eş anlamlı olarak kullanılmıştır. Clauson, kelimenin büyük ihtimalle alıntı kelime olduğunu ileri sürmüştür (Clauson, 1972, 967). Birçok Türkolog tarafından farklı açıklanan kelimenin kökeni Doerfer tarafından "yarmak" fiiline, Tekin tarafından "salya" anlamına gelen "yar" ismine ve diğer bazı araştırmacılar tarafından ise, daha tutarlı bir görüş olarak, Moğolcada "haber, bildirge" anlamına gelen "car" kelimesinin Türkçede teorik olarak karşılığı varsayılan “*yar” isim köküne dayandırılmıştır.

yarmaḳ: Altın ve gümüş sikke, hazine, (zer, NḲ 97a-7).

\section{Yüksek Askerî Komutanlıklar ve Memuriyetler}

başıı̣: Komutan, (serdār, NTDL 6b-9).

berikī: 1. Maliye idaresinin başı, haznedar, 2. Mahkeme başkanı. Bkz. ėşik ağası, (dārūğa-i dīvān-ḩāne, ZET 84b-16).

Kelime, Türkçe kökenli “berk” (sağlam, emin) köküne gelen Arapça “+ł” nispet

5 Bu konuda genel bir değerlendirme için bkz. Güner, 2013. 
ekiyle oluşmuş “berkî̄” kelimesinin yapısında meydana gelen ünlü türemesi sonucu aldığ şekil olmalıdır: berkī > beriki. "Berk" kelimesi, 14. yüzyılda yazılmış Oğuzca Bahşayiş Lügati’nde Arapça “emin” kelimesinin karşılığı olarak “güvenilir insan, mutemet” anlamında kullanılmıştır ki kelimenin anlamı haznedar ve mahkeme başkanının gerektirdiği özelliği yansitmaktadir (bkz. Turan, 2017, 61).

çalış: Asker, memur ve kölelere yapılması gerekli işleri bildiren komutan veya âmir? (her ḥākimī ki be-reved yād-ı nöker şeved ve ḥaḳiḳat be-gūyed, ZET 86a-4).

çėrik başlıḳ: Yüksek rütbeli ordu komutanı, general, (sipeh-server, sipeh-sālār, NḲ 10814, ZET 85a-4).

çèrikçi: Emrinde asker bulunduran veya devlet için asker besleyen yüksek devlet memuru veya askerî komutan, tımarlı sipahi, (leşkerī ve sipāhī, ZET 85a-4).

daruġa: Moğ. 1. Vali, kaymakam, 2. Yüksek dereceli daire müdürü, âmir, (ḳā' im-maḳām, NTDL 7a-5).

Kelime Moğolca "basmak" anlamındaki “daru-" fiil kökünden türemiştir. Aynı anlamdaki Türkçe "basmak" fiilinden türeyen "baskak" da benzer işlevdeki idari görevler için kullanılmıştır ${ }^{6}$. Darugalar Moğol Devletinde 13. yüzyıldan itibaren bir şehrin hem askerî hem de idari üst düzey yöneticileri olarak esasen vergilerin toplanmasında ve merkezî idarenin istediği düzenlemeleri yapmakla yükümlü vali derecesinde yöneticilerdi. Kelime, Cengiz Han'ın ölümünden sonra çeşitli seviyelerde idari memuriyetler için Moğolların ve onların devamı olan devletlerde kullanılmaya devam etmiştir. Farsçaya da "dārūga" şeklinde geçtikten sonra zamanla anlam değişikliğine uğramış ve daha küçük devlet görevlileri için kullanılır olmuştur. Darugalar, Babürlüler döneminde hem merkezde hem de taşrada benzer görevleri yürüten üst düzey memurlardı. Bununla birlikte daha küçük dağlık taşra şehirlerinde devleti temsil eden memurlar için de daruga terimi kullanılmıştır (Borooah, 2000).

èşik ag̉ası ėşik ag̉a: 1. Maliye idaresinin başı, haznedar, 2. Mahkeme başkanı, 3. Sarayın kapılarından sorumlu üst düzey yönetici, kapıcı başı. Bkz. beriki, (dārūğga-i dīvānhāne, derbān, NT 8b-9, ZET 84b-9).

ḳoşun bẻgi: On bin kişilik ordu komutanı, (serdār-1 deh-hezār kes, ZE 85a-9).

küçüm: Emrinde çok mal, mülk ve asker bulunduran ileri gelen kişi, ayan, tımarlı sipahi, (merdī ki șạhib-i māl u sipāh, NTDL 13a-11).

miñ başı: Binbaşı, bin kişilik ordu birliğinin komutanı. Bkz. miñ bègi, tümen başı, tümen bègi, (serdār-1 hezār-kes, ZET 85a-1).

miñ bẻgi: Binbaşı, bin kişilik ordu birliğinin komutanı. Bkz. miñ başı, tümen başı, tümen

6 Kelimenin kökeni ve anlamları için bkz. Bosworth \& Clauson, 1965; Poppe, 1966; Vásáry, 1976. 
bègi, (serdār-1 hezār-kes, ZET 85a-1).

müşrīf: $A r$. Daire müdürü, üst düzey âmir, (emīn, NTDL 10a-1).

topçı başı: Tophane komutanı, tophane âmiri, (dārūgag-i tophāne, ZET 84b-17).

tuġçı: Padişahın tuğunu ve mührünü taşıyan memur, (nişān-berdār, ZET 85a-2).

tuḳbay: 1. Protokol ve inzibat âmiri, 2. Komutan, (mīr-i tūzāk, ZET 85a-2).

tümen başı: Binbaşı, bin kişilik ordu birliğinin komutanı. Bkz. tümen bègi, miñ başı, miñ bègi, (serdār-1 hezār-kes, ZET 85a-1).

Tümen kelimesinin Toharca "tmān" veya "tumane" kelimesine veya Çince on bin anlamındaki "wan" kelimesine dayandığı Clauson tarafından ileri sürülmüştür. Esasen "on bin" anlamındaki bu kelime büyük sayı ve miktarlar için kullanılan bir belgisiz sıfat olarak kullanılsa da Türkçede daha çok askerî bir terim olarak görülür (Clauson, 1972, 507). Kelime, buradaki "tümen başı" ve "tümen begi”" yapıları içinde "bin kişilik askerî birlik" anlamındadır.

tümen bėgi: Binbaşı, bin kişilik ordu birliğinin komutanı. Bkz. tümen başı, miñ başı, miñ bègi, (serdār-1 hezār-kes, ZET 85a-1).

\section{Alt Askerî Rütbeler, Memurluklar ve Görev Alanları}

ahttaça: Baş seyis (mīr-āhuūr, NT 24a-1).

Kelime, Moğolca "aḩta” (iğdiş, iğdiş edilmiş at, hadım) kelimesiyle Türkçe $+c ̧ A$ ekinden türemiştir. Çeşitli Türk lehçelerinde ve Farsçada bu kelime daha çok meslek eki + çI ile “ahtaçı” şeklinde kullanılmıştır (Barutçu-Özönder, 1996, 34; Morgan, 2011).

alug̣çı: Vergi memuru, tahsildar, vergi toplayan, (camel-dār, ZET 84b-11).

bitikçi: Kâtip, yazıcı, (ḳalem-zen, NK 105a-10).

Kelime "biti-“ fiilinden türemiş bitik (yazılı belge, kitap) ismine gelen +çI meslek ekiyle oluşmuştur. "Biti-" fiilinin Çincede "yazı firçası" anlamına gelen "piětt” kelimesine dayandığı ileri sürülmüş olsa da bazı bilim adamları bu görüşün fonolojik olarak açıklanmasının zorluğundan bahseder (Sinor, 2012b).

çavuş: Öncü asker, askerlerden önce gidilecek yere giden keşif kolu askeri, (merdī ki ez berā-yı menzil-dīden pīşter ez leşker bereved, ZET 86a-3).

Kelime, Tonyukuk Yazıtında baş komutan veya yüksek rütbeli komutan anlamındaki “çabış" kelimesine dayanır (Tekin, 2003, 101). Kelime sonraki dönemlerde daha alt rütbeli askerî komutanlıklar ve polis memurlukları için kullanılmış olsa da çeşitli Türk devletlerinde 
sivil bürokraside kapıcı, haberci takım başı veya grup lideri anlamında da kullanılmıştır (Clauson, 1972, 399). Kelime Babürlülerde sefere çıkan birliklerden önce gidilecek yerleri keşfe çıkan öncü askerler için kullanılmıştır.

esre: Bekçi, gözcü, (nigāhdār, NḲ 101a-10).

ėşikçi: Kapıc1, kapı muhafızı, (derbān, ZET 84b-10).

on başı: Onbaşı, on kişilik birliğin komutanı. Bkz. on bègi, (serdār-1 deh kes, ZET 84b-9).

on bėgi: Onbaşı, on kişilik birliğin komutanı. Bkz. on başı, (serdār-1 deh kes, ZET 84b-9).

yüz başı: Yüzbaşı, yüz kişilik birliğin komutanı, (serdār-1 șad kes, ZET 86b-12).

\section{Savaş, Güvenlikle ve Alt Düzey Asker ve Polisle İlgili Kelimeler}

alp: Yiğit, bahadır, kahraman, (NK 104a-7).

atlıḳ: Atlı, süvari asker, (sūvār, NḲ 96b-6, ZET 84b-10).

atlu atlı: Atlı, süvari asker. Bkz. atlık (sūvār, ZET 84b-10, NK 96b-6, 119).

baranġar buranġar: Moğ. Muharebe düzeninde ordunun sağ kolu, (fevc-i dest-rast, fevc-i yemīne, NT 9a-4, ZE 84b-14).

basalġa: Karavulun ardındaki baskın kuvvetleri. Bkz. basturma, (fevcī ki ba 'd-i ḳaravul bāşed ZET 84b-13).

basturma: Karavulun ardındaki baskın kuvvetleri. Bkz. basalg̀a, (fevcī ki ba 'd-i ḳaravul bāşed ZET 84b-14).

batur: Yiğit, gözüpek, kahraman, (bahadur u dilāver, ZET 85b-9).

Kelime, Moğolca kökenli aynı anlamdaki "baġatur / bahadur" kelimesinden orta hece düşmesi (haploloji) sonucu oluşmuş olmalıdır (Sinor, 2012a).

boynaġu: Asi, inatçı ve başkaldırıcı, (gerden-keş ZET 84b-16).

Kelime, "boyun" kelimesine vücut özelliğini öne çıkaran kelimeler yapan + AgU ekinin eklenmesiyle oluşmuştur: Boyunag்u > boynag̉u (Erdal, 1992, 162).

böyrekçi: 1. Düşmana tuzak kuran, tuzak hazırlayan askerî birlik, 2. Düşmana yan cenahtan saldıran birlik (fevc-i kemīn-gāh u pehlū-kūb-i ganīm, ZET 84b-15).

Kelime "bögür" (vücudun yan kısmı, yan taraf) ve "bögrek” (böbrek, vücudun böbrek tarafi) kelimesine dayalı olarak oluşmuştur.

çapavul: Padişahın çevresinde bulunan ve tahtı taşıyan seçkin askerler, hassa askerleri? 
(fevc-i nāzende ve tah̆t-ārende, ZET 85a-6).

Sözlüklerde genel olarak "çapulcu ve yağmacı gruplar” olduğu açıklanan "çapavul” kelimesi ZET'de padişahın hassa askerleri olarak gösterilmiştir.

çaranġar çuranġar: Moğ. Muharebe düzeninde sol koldaki askerî birlikler, (dest-i çep ender vegā, fevc-i dest-i çep-i bādişāh, NT 9a-5, NTDL 5a-7, ZET 85a-4).

çèrik: Asker, er, (leşker, NT 21b-4, NTDL 6b-8, ZET 85a-3).

çındavul: $M o \breve{g}$. Muharebe düzeninde ordunun arka safları, (cem '̄i ki rūz-1 ceng pes ez leşker, cem ‘̄i ki dunbel-end der rāh u sefer, fevcī ki rūz-i ceng der caḳab-i leşker bāşed, NT 22b-4, NTDL 14b-8, ZET 85a-5).

èletmiş: Öncü birlik, (fevc-i pīş-ḡūl, ZET 84b-12).

Kelime "èlet-“ (göndermek) fiilinden -mIş sıfat-fiiliyle oluşmuştur. En önce gönderilmiş askerî birlik anlamında görülür.

èrçi: Elçi, arabulucu. Bkz. yapçı, (resūl ve miyānçı, ZET 84b-8).

gol: Moğ. Muharebe düzeninde merkezi tutan birlikler, (fevc-i der-miyāne, NḲ 96b-9). Moğolcanın Kalmuk ağızlarında "merkez" anlamında olan bu kelime Türkçeye buradan geçmiştir (Brophy, 2001).

Iravul hıravul: Moğ. Muharebe düzeninde ordunun ön safları, (fevc-i pīş rūz-1 ceng, ZET 84b-8).

Kelime önce Nevâyî tarafından "hıravul" şeklinde tespit edilmiş, ancak sonraki kaynaklarda her iki varyant da yaygın olarak gösterilmiştir (Barutçu-Özönder, 1996, 42). Kelime "irevül / hirevül”" şeklinde ince ünlülerle okunabilse de benzer yapıdaki kelimelerin çoğunun kalın ünlülerle olmasından dolayı kelimeyi kalın ünlüyle okumayı tercih ettik (Kara, 2011, 335).

kapuçı: Düşmana tuzak kuran ve yan cenahtan saldıran birlikler, (pehlū-kūb-1 ġanīm ve der kemīn-gāh istāde ve gūş bād ez nişeste, ZET 85a-10).

Kelime "ḳap- fiilinden” -IçI (<-gIcI) sıfat-fiiliyle kurulmuştur: ḳapıçı > ḳapuçı. Aynı fiil kökünden tuzak anlamına gelen "kapan” kelimesi de Türkiye Türkçesinde bir başka sıfatfiil olan - An $(<\mathrm{gAn})$ ekiyle oluşmuştur. Bu bakımdan her iki kelime arasında yapısal ve semantik paralellikler vardır.

ḳaraḳçı: Yol kesen harami, eşkıya, soyguncu, (rehzen ve ḳıtācu’ț-ṭarīk, ZET 85a-10).

ḳaravul: Keşif müfrezesi, (fevc-i dīd-bān ki pīş ez ıravul berā-yi ḩaber-i düşmān reved, ZET 85a-6). 
Sözlüklerde güvenlik âmiri, polis âmiri ve güvenlik görevlileri anlamında görülen "ḳaravul” burada ordu birliklerinden önce gidip düşman hakkında bilgiler getiren keşif müfrezesi anlamında gösterilmiştir (Ünlü, 2013, 584).

kèleçi: Haberci, postacı (ḳāṣid, ZET 86b-5).

ḳoruḳçı: Korucu, padişahın avlanma alanları ile ekili arazileri koruyan güvenlik görevlisi, polis, korucu, (men' kunende, merdī ki şikārgāh-1 bādişāh ve zirācat-1 recayā-rā ez huūrāndān-i mal, nigāh-dār ve mānic şeved, in çenīn kes-rā der Hindūstān der-īn zamān cāmdār gūyend, NK 94a-15, ZET 85a-6).

ḳoruḳmal: Korucu. Bkz. ḳorukçı, (ZET 85a-6).

köñüllük: Gönüllü savaşçı, yiğit ve kahraman, (pur-dil u dilāver ve rāġıb-1 derkār u evāmir, ZET 86b-2, NḲ 95a-15).

ḳurg̉ançı: Korucu, bkz. ḳorukçı, ḳoruḳmal (ZET 85a-6).

küçlük küşlük: Küçük yerleşim birimlerinin veya işyerlerinin başı, muhtar, kâhya, (kedhudā ZET 86b-4).

saḳlaçı: Bekçi, gece bekçisi, (pāsbān, ZET 86a-10).

Kelime, "saḳla-" fiilinden -gUçI sıfat-fili ekiyle türedikten sonra orta hecelerden ikicisinin düşmesiyle oluşmuştur: saḳla-ğuçı > saḳlaçı.

tilçi: Casus, (cāsūs, ZET 86a-2).

töreçi: Haksızlığa uğrayanın hakkını koruyan memur, kanun ve kuralları bilen hukuk adamı, bir tür savcı ve avukatlık görevi (be-dād-ı maẓlūm resānde, ZET 85b-16).

Kelime kanun, kural ve geleneksel uygulama anlamına gelen “töre < törü” kelimesiyle + çI meslek ekinden oluşmuştur. Verilen açıklamaya dayalı olarak, kelimenin haksızlığa uğradığını düşünen kişilere örfi hukuk (yasa) içinde yol gösteren ve hukuki destek veren devlet görevlisi olmalıdır.

tusḳavul tuşḳavul: Öncü akıncı birliği, akıncı, yol muhafızı. Bkz. tutkavul, (fevc-i rehgīr-i ganīm, fevc-i rāh-gīr der pīş-rāh-1 ġanīm, NK 97b-8, ZET 85a-3).

tutg்un: Mahpus, esir, (merd-i muḳayyed, maḥbūs ve girifte-şude, ZET 85b-15).

tutḳavul: Öncü akıncı birliği, akıncı, yol muhafızı. Bkz. tuskavul, tuşkavul, (ZET 85a-3).

Köprülü'ye göre "tutḳavul” bir memuriyet olarak önceleri devlet adına kervanlardan yol vergisi alan ancak sonraları bu vergiyi keyfi olarak toplayan kişiler için kullanılmıştır. (Köprülü, 1983.) ZET'den anladığımız kadarıyla kelime Babürlülerde askerî bir terim olarak öncü akıncı birlikleri için kullanılmıştır. 
uruşçı: Savaşçı, muharip asker, (cengī, merd-i cengī, NĶ 95a-12, ZET 84b-10).

yag̀ı: Düşman, yağı, hasım. Bkz. yavğ $l$, yav, (ġanīm, ZET 86b-9).

Kelime Göktürk Yazıtlarında da "yağı” şeklindedir: Tört buluñ ḳop yaġı ermiş (Dört taraf hep düşman imiş) (Tekin, 2003, 38).

yapçı: Elçi, arabulucu, (resūl ve miyānçi, ZET 84b-8).

yaraḳ: Silah, (silah, NK 95b-3).

yasa yasal: Moğ. Asker veya polis devriyesi, müfreze, (NḲ 104a-14). Esasen padişahın koyduğu örfi kanun ve kural anlamına gelen "yasa" sonradan bu kanunların ve kuralların uygulamasını sağlayan ve gözeten polis ve askerler için kullanılmış olmalıdır.

yasavul: Moğ. Asker veya polis devriyesi, müfreze. Bkz. yasa-yasal, (NḲ 104a-15).

yav: Düşman, yağı, hasım. Bkz. yavg் dönüşen kelimenin "yaw" ve "yü” şekli daha çok Kuzey lehçelerinde görülür (Clauson, 1972, s. 898).

yavġı: Düşman, yağı, hasım. Bkz. yağl, yav, (ġanīm, ZE 85a-11).

yayaḳ yayaġ: Yaya, yaya asker, piyade asker, (piyāde, ZE 86b-10).

Kelime, Eski Türkçe metinlerde yaygın olarak kullanılan ve "yaya, yürüyerek giden" anlamındaki "yadag்" kelimesinden gelmiştir. Kelimenin çeşitli lehçelerde "yaya" ve vasıta hali ekiyle genişlemiş "yayan” şeklinin yanı sıra "yayav" şekli de görülür (Clauson, 1972, s. 887).

yayçı: Yaycı, (kemān-ger, ZE 86b-8).

yol urg̉uçı yol tutḳuçı: Yol kesen eşkıya, haydut, soyguncu. Bkz. karakçı, (rehzen ve ḳıtācu’ț-țarīk, ZE 85a-13).

yortavul: Çapulcu alayı, yağmacı saldırgan grup, (fevc-i gāaret-ger, NḲ 61-5).

yörüş: Düşman üzerine saldırı, hücum, (hele kerden ber ser-i ganīm, ZET 85a-13).

\section{SONUÇ}

İncelediğimiz Babürlü dönemine ait Farsça-Çağatay Türkçesi sözlükler, Babürlü Devletinde idari ve askerî terim olarak kullanılan birçok kelime ve kelime birliğini açıklamaktadır. Bu kelimelerin ve kelime birliklerinin dilbilimsel özellikleri şöyledir:

a. İncelediğimiz sözlüklerde daha önceki Türk veya İslam devletlerinde idari ve askerî sistem içinde kullanılmayan veya çok sınırlı kullanımı olan kelimeler bulunmaktadır. İdari ve askerî terim haline gelen bu kelimeler şunlardır: aluģçı, basalġa, beriki, boynag்u, böyrekçi, èletmiş, esre, kapuçı, küçüm, öçek, öründük, tabçı, tukbay, yapçı. 
b. Bu sözlüklerde daha önceki dönemlerde kullanılan, ancak Babürlü Devletinde anlam değişimine uğrayan şu kelimeler ortaya konmuştur: ahtaça, ak, akç̧a, bahşi, basturma, başlık,

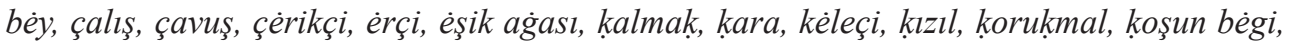
kurg்ançı, müşrīf, saḳlaçı, tilçi, töreçi, tura, tutkavul, yasa, yasal, yol urg்uçı.

c. Babürlü Devletinde kullanılan idari ve askerî kelimelerin önemli bir kısmı daha önce Timurlular döneminde de kullanılan ve Türkçeleşmiş Moğolca kökenli kelimelerdir. Babürlü hanedanının kurucusu Babür Şah'ın anne tarafından Cengiz Han soyundan gelmiş olmasının sonucu olarak Babürlü devlet mekanizmasında Moğolca kökenli kelimeler çokça kullanılmıştır. İncelediğimiz sözlüklerde görülen Moğolca kökenli kelimeler şunlardır: ahta, barang்ar burang்ar, batur, çarang்ar çurangar, çındavul, darug்a, gol, ıravul hiravul, yasa yasal, yasavul.

d. Ele alınan konudaki Türkçe kelimelerin bazıları ses ve yapı değişimine uğramış kelimelerdir: érçi (<èlçi), esşik a $\dot{g} a$ (<èşik ag̉ası), küşlük (<küçlük), yapçı (<yapg்uçı), saklaçı (<saklağuçı), yav yavg் (<yag்i).

e. Adı geçen kelimelerin önemli bir kısmı yapı yönünden türemiş kelimelerdir. Türemiş kelimelerin yapısı şöyledir:

i. Türemiş kelimelerin büyük kısmı meslek yapım eki olan +çI ile yapılmıştır: aluggçı, bitikçi, böyrekçi, çèrikçi, érçi, ėşikçi, karakçı, ḳorukçı, kurg்ançı, tabçı, tilçi, topçı, töreçi, tug

ii. +lIk eki hem isimden isim, hem de isimden sıfat eki olarak yapım eki işlevinde yaygındır: başlık, bèklik, érklik, èrtelik, kön̈̈̈llük, küçlük küşlük.

iii. Sıfat-fiil ekleri: èletmiş, kèleçi (<kelgüçi), kurg்an (<ḳorug̉an), öründük, saḳlaçı (<saḳlaġuçı), tutg்un, yol urg்uçı, yol tutkuçı.

iv. Eşitlik hali eki +çA yapım eki işlevinde az sayıda kelimede görülür: akça, ahtaça.

v. Daha az sayıda kelimede isimden isim +ma (basturma),+mal (koruḳmal), +aǵu (boynag̉u), Arapça nispet eki +ī (bègī, berikī), fiilden fiil -Alg̀A(basalg̉a) kullanılmıştır.

f. Az sayıda idari ve askerî terim iki kelimeden oluşmuştur. Bu yapıların çoğu belirtisiz isim tamlaması şeklindedir.

i. Bu yapıdaki kelime grupları liderlik ve komutanlık bildiren "ag̉a," "baş" ve "bèg"

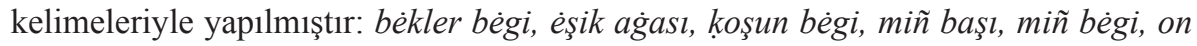
başı, on bégi, topçı başı, tümen başı, tümen bègi, yüz başı.

ii. Daha az sayıda terim takısız isim tamlaması şeklinde görülür: çérik başlık, ęşik ag்a, tukbay.

iii. Sifat tamlaması: iki kara.

iv. Sifat-fiil grubu: yol urg்uçı yol tutkuçı.

Finansal Destek: Yazar bu çalışma için finansal destek almamıştır. 


\section{KAYNAKÇA}

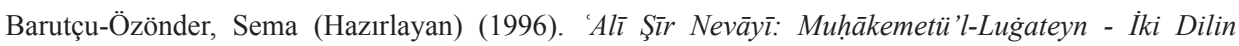
Muhakemesi, Ankara: Türk Dil Kurumu.

Begmatov, E., A. Madvaliev, N. Mahkamov, T. Mirzayev, N. Töhliev, E. Umarov, D. Hudoyberganova, A. Hociev (2006). Özbek Tilinin İzohli Luğati, 5 cilt, Toşkent: Özbekistan Respublikası Fanlar Akademiyası.

Blochet, E. (1933). Catalogue des Manuscrits Turcs, Cilt II, Paris: Bibliothèque Nationale.

Bodrogligeti, A. J. E. (1981). "A Glossary to the Rylands Eastern Turkic-Persian Versified Vocabulary," Ural-Altaische Jahrbücher, Cilt 53, s. 1-65.

Borooah, Romy (2000). "Transformations in Trade and the Constitution of Gender and Rank in Northeast India," American Ethnologist, Cilt 27/2, s. 371-399.

Bosworth, C. E. \& Gerard Clauson (1965). "Al-Xwārazmī on the Peoples of Central Asia," The Journal of the Royal Asiatic Society of Great Britain and Ireland, No 1/2 (April 1965), s. 2-12.

Brophy, David (2011). "Mongol-Turkic Languages Contact in Eighteenth Century Xinjiang: Evidence from the Islāmnāma," Turkic Languages, 15/1, s. 51-67.

Clauson, Sir Gerard (1972) An Etymological Dictionary of Pre-Thirteenth Century Turkish, Oxford: Clarendon Press.

Clauson, Sir Gerard (Hazırlayan) (1960) Sanglax - A Persian Guide to the Turkish Language by Muhammad Mahdī Xān, London: Trustees of the E. J. W. Gibb Memorial.

Devellioğlu, Ferit (1997) Osmanlıca-Türkçe Ansiklopedik Lûgat, 14. Baskı, Ankara: Aydın Kitabevi.

Doerfer, Gerhard (1963-1975) Turkische und Mongolische Elemente im Neupersischen, 4 cilt, Wiesbaden.

Eckmann, János (1966) Chagatay Manual, Bloomington: Indiana University.

Eraslan, Kemal (2012) Eski Uygur Türkçesi Grameri, Ankara: Türk Dil Kurumu Yayınlar1.

Erdal, Marcel (1992) Old Turkic Word Formation, 2 cilt, Turcologica 7, Wiesbaden: Otto Harrassowitz.

Eren, Hasan (1999) Türk Dilinin Etimolojik Sözlüğü, Ankara: Bizim Büro Basım Evi.

Eren, Hasan (1950) “Çağatay Lûgatleri Hakkında Notlar,” DTCF Dergisi, Cilt VIII/1-2, s. 145-163.

Eşref, Ahmet Bahtiyar \& Celal Soydan, Urdu-Türkçe, Türkçe Urdu Sözlük, İstanbul: Türk Dil Kurumu.

Faruqui, Munis (2009) “At Empire's End: The Nizam, Hyderabad and Eighteenth-Century India," Modern Asian Studies, Cilt 43/1, s. 5-43.

Gülensoy, Tuncer (1974) Eski ve Orta Türkçede Moğolca Kelimeler ve Moğolca-Türkçe Müşterek Kelimeler Üzerine Notlar, Türkoloji Dergisi, Cilt VI/1, s. 235-259.

Güner, Galip (2013) 'Yarlıg 'Buyruk, Emir, Ferman' ve Yarlıka- '(Tanrı) Buyurmak; Lütfetmek' Kelimelerinin Üzerine Yeni Görüşler,” Turkish Studies, Cilt 8/1, (Kış 2013), s. 1553-1560.

Irvine, William (1903) The Army of the Indian Moghuls: Its Organization and Administration, London: Luzac.

Kara, Funda (Hazırlayan) (2011) Zebân-ı Türkî (Kelür-Nâme): Inceleme, Metin, Dizin, Erzurum: Fenomen Yayıncilik.

Khalid, Adeeb (1991) "The Residential Quarter in Bukhara before the Revolution (The Work of O. A. Sukhareva)," Middle East Studies Association Bulletin, Cilt 25/1, s. 15-24.

Köprülü, Fuad. 1983. "Eski Türk Unvanlarına Ait Notlar," İslâm ve Türk Hukuk Tarihi Araştırmaları ve Vakıf Müessesesi, Hazırlayan: Orhan F. Köprülü, İstanbul: Ötüken Neşriyat, s. 87-101. (Baskısı: Türk Hukuk ve İktisat Tarihi Mecmuası, C. II, İstanbul, 1938, s. 17-31) 
Krippes, A. Karl (1996) Uzbek-English Dictionary, Kensington: Dunwoodly Press.

Krippes, A. Karl (1994) Kazakh (Qazaq)-English Dictionary, Kensington: Dunwoodly Press.

Necip, Emir Necipoviç. 1995. Yeni Uygur Türkçesi Sözlüğ̈̈, Rusçadan çeviren: İklil Kurban, Ankara: Türk Dil Kurumu.

Morgan, D. O. “Aktaji,” Encyclopaedia Iranica, Cilt I/7, s. 730.

Musayev, O, I. (Editör) (1998) Azerbaycanca-İngilisce Lüğet, Baki: Azerbaycan Dövlet Diller İnstitutu.

Poppe, Nicholas (1966) “On Some Ancient Mongolian Loan-Words in Tungus," Central Asiatic Journal, Cilt 11/3, s. 187-198.

Redhouse, Sir James W. (1987) A Turkish and English Lexicon, New Edition, Beirut: Librairie du Liban.

Schimmel, Annemarie (1981) "Türkisches in Indien," Scholia: Beiträge zur Turkologie und Zentralasienkunde - Annemarie von Gabain zum 80 Geburstag am 4. July 1981 dargebracht von Kollegen, Freunden und Schülern. Wiesbaden: Otto Harrassowitz, s. 156-162.

Schmidt, Jan. (2011) A Catalogue of the Turkish Manuscripts in the John Rylands University Library at Manchester, Leiden: Brill.

Shaw, Robert Barkley (2014) Kâşgar ve Yarkend A ğzı Sözlüğü, Çeviren Fikret Yıldırım, Ankara: Türk Dil Kurumu.

Sinor, D. (2012a) "Bahādur," Encyclopaedia of Islam, Second Edition, Eds.: P. Bearman, Th. Bianquis, C.E. Bosworth, E. van Donzel, W.P. Heinrichs. http://dx.doi.org/10.1163/1573-3912_islam_ SIM_1035 (11 Ocak 2019)

Sinor, D. (2012b) "Bitikči” Encyclopaedia of Islam, Second Edition, Eds.: P. Bearman, Th. Bianquis, C.E. Bosworth, E. van Donzel, W.P. Heinrichs. http://dx.doi.org/10.1163/1573-3912_islam_SIM_1459 (11 Ocak 2019)

Steingass, F. (1989) A Learner's Arabic-English Dictionary, New Impression, Beirut: Librairie du Liban.

---. (1892) A Comprehensive Persian-English Dictionary, London: Routledge K. Paul.

Şeyh Süleyman Efendi-yi Buhârî. (1298/1880) Lügat-i Çağatay ve Türkî̀-yi Osmânî, İstanbul: Mihran Matbaas1.

Tekin, Talat (2003) Orhon Yazıtları, İstanbul: Yildız.

Tekin, Talat. Mehmet Ölmez, Emine Ceylan, Zuhal Ölmez, Süer Eker (1995) Türkmence-Türkçe Sözlük, İstanbul: Simurg.

Turan, Fikret (2017) Bahşâyiş Bin Çalıça, Bahşayiş Lügati, Ankara: Türk Dil Kurumu.

---. (2009) “Turkic Grammar Books Written in Mughal India during the 18th and 19th Centuries," Turkic Languages, Cilt 13, s. 163-171.

Türkmen, Erkan (1985) "Hindistan kütüphanelerindeki bazı Türkçe yazma eserler," Türk Kültürü Araştırmaları - Prof.Dr. İbrahim Kafesoğlu’nun Hâtırasına Armağan, Cilt XXIII/1-2, s. 479-499.

Ünlü, Suat (2013) Çağatay Türkçesi Sözlüğü, Konya: Eğitim Yayınları,

Vásáry, István (1976) "The Golden Horde Term Daruga And Its Survival in Russia," Orientalia Academiae Scientiarum Hungaricae, Cilt XXX/2, s. 187-197.

Véliaminof-Zernof, V. de (Hazırlayan) (1869) Dictionnaire Djaghataï-Turc, Saint-Pétersbourg: Imprimerie de 1'Académie Impériale des Sciences.

Wurm, Stefan (1947) “The Uzbek Dialect of Qïzil Qujaš,” Bulletin of the School of Oriental and African Studies, Cilt 12/1, s. 86-105.

Yakup, Abdurishid (2005) The Turfan Dialect of Uyghur, Turcologica 63, Wiesbaden: Harrassowitz Verlag. Yüce, Nuri (Hazırlayan) (1988) Ebu'l-Kāsım Cārullah; Mukaddimetü'l-Edeb, Ankara: Türk Dil Kurumu. Yudahin, K. K. (1994) Kırgız Sözlüğ̈̈, 2 cilt, Çeviren: Abdullah Taymas, Ankara: Türk Dil Kurumu. 